\title{
Intergovernmental planning and budgeting in Zimbabwe: learning the lessons of the past
}

\section{Commonwealth Journal of Local Governance}

Issue 20: December 2017

http://cjlg.epress.lib.uts.edu.au/

\section{Tinashe C Chigwata}

Dullah Omar Institute for Constitutional Law, Governance

and Human Rights

University of the Western Cape

South Africa

Email: tchigwata@uwc.ac.za

tchigwata@gmail.com

\section{Sylvester Marumahoko}

School of Postgraduate Studies

University of Johannesburg

South Africa

Email: smarumahoko@uj.ac.za
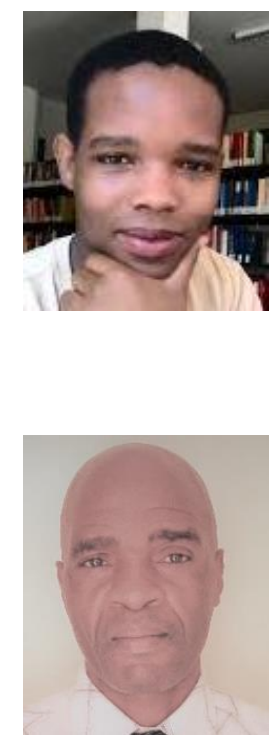

\begin{abstract}
In Zimbabwe, the Prime Minister's Directives on Decentralisation and Development of 1984 and 1985 , together with the Provincial Council and Administration Act 1985, constitute the foundation for postindependence attempts to ensure effective governance. The Directives provided for the establishment of hierarchical structures and mechanisms to coordinate government activities, including development planning at various levels of government. This paper asks whether these structures and mechanisms have been effective in promoting 'sound' intergovernmental planning and budgeting, and whether they are still relevant given that in 2013 Zimbabwe adopted a new Constitution with greater promises, visions and demands than its predecessor, the Lancaster House Constitution. The paper argues that the adoption of a new Constitution provides a valuable opportunity to reform the intergovernmental planning and budgeting process, which to date has proved ineffective in fostering integrated and coherent effective governance.
\end{abstract}

\section{Introduction}

The Prime Minister's Directives on Decentralisation and Development of 1984 and 1985 provide the foundation for independent Zimbabwe's attempts to foster integrated and coherent government. Together with the Provincial Council and Administration Act, Chapter 29:11 of 1985, the Directives 
established various institutions and mechanisms to facilitate development planning at various levels of government. This paper examines the effectiveness of these institutions and mechanisms - as well as their relevance, since a new constitution was promulgated in 2013 , under which provincial and local governments are now tiers of government with directly vested authority.

\section{Methodology}

This paper uses desktop research to review relevant literature, policies and legislation relating to intergovernmental planning and budgeting in Zimbabwe, and multi-level government in general. It seeks first to define the concept of intergovernmental planning and budgeting and provide an overview of Zimbabwe's three-tier system of government. It then examines the institutions and mechanisms of intergovernmental planning and budgeting in Zimbabwe, and offers some proposals to improve their functioning, followed by concluding remarks.

\section{Defining intergovernmental planning and budgeting}

Under a multi-level system of government, the various levels of government share powers, responsibilities and resources in order to maximise the state's potential to realise development, deepen democracy and sustain peace (Chigwata 2015). In some countries each level of government is responsible for a set of functions over which it has exclusive competence. Alternatively, governments at various levels may share competence for certain functional areas, or exercise their competence within frameworks set by government(s) at higher levels.

However, even if the governments have exclusive responsibility for a set of functions, they all have a combined responsibility to ensure that the public good is realised (De Visser 2005). Competition between them is unlikely to bring about this result. Rather, the tiers of government must cooperate and coordinate their activities to ensure integrated and coherent governance (De Visser 2005), which requires the alignment of policies and priorities across all levels of government (Department of Provincial and Local Government, South Africa 2007). Intergovernmental planning and budgeting is one of the mechanisms which can be effective in realising this objective.

Intergovernmental planning and budgeting is defined in this paper as the process through which two or more tiers of government align their policies and priorities through strategic (development) planning and budgeting in order to deliver on their individual and combined constitutional and legislative mandates. This definition expands the scope of planning from being concerned only with control of land use to become a "management tool that 'gives life' to many aspects of decentralisation by leveraging in the benefits of these processes and ensuring that the desired outcomes are achieved" (Hadingham 2003). Planning is thus concerned with efficient distribution of scarce resources, coordination of government activities across sectors and pro-poor development, among other factors (Hadingham 2003). A key aspect of this intergovernmental planning process is that each level of 
government must also consider the other levels' policies and priorities when formulating their own policies and budgets (Department of Provincial and Local Government, South Africa 2007). In Zimbabwe, this is in principle achieved through the development (strategic) planning and budgeting process (discussed below).

\section{Zimbabwe's system of government}

Zimbabwe adopted a new Constitution in 2013, the Constitution of Zimbabwe Amendment (Number 20) Act 2013, which among other things provides for a three-tier system of government. Before the adoption of this constitution, the country was governed by the Lancaster House Constitution of 1979, which featured a unitary form of government in which only the national government had direct constitutional authority, and thus sole discretion to determine state organisation. For example, the provincial councils and local government which then existed were creatures of national legislation although provincial governors and traditional chiefs did have constitutional recognition.

The 2013 Constitution ushered a new era in which government is organised at the national, provincial and local levels. Central government operates through ministries and agencies that are organised at the national level with some having offices at the provincial and local levels. Provincial and metropolitan councils provided in the Constitution, govern the eight non-metropolitan provinces and the two metropolitan provinces, respectively (see Sections 268 and 269 of the 2013 Constitution of Zimbabwe). The local tier of government is constituted by urban and rural local authorities, with the former responsible for administering urban areas, and the latter administering rural areas alongside the institution of traditional leadership of chiefs, headmen and village heads (see Sections 274, 275 and 282 of the 2013 Constitution of Zimbabwe). Some $67 \%$ of Zimbabwe's population lives in rural areas where traditional leadership constitutes the immediate form of local government (Chigwata 2015).

Provincial and local governments are thus now constitutional bodies whose existence does not rely on the 'goodwill' of the national government but originates from the Constitution. However, although local government is fully operational, provincial and metropolitan councils have at the point of writing not been established owing to, among other reasons, the absence of relevant operationalising legislation. Significant areas of legislation governing local government have also yet to be aligned with the 2013 Constitution.

The 2013 Constitution's vision for devolved government is wide-ranging (see Section 3(21), the Preamble of Chapter 14 and Section 265(1)). It envisages provincial and local governments exercising delegated powers, and devolves powers to realise development, democracy and peace. These include powers to raise revenue, appoint staff and carry out certain functions. However, as seen above, once these powers and responsibilities are decentralised, mechanisms for ensuring that the activities of the 
three tiers of government are aligned and coordinated become critical if effective government is to be assured (De Visser 2005).

Since independence, the ZANU-PF government has put in place various measures to coordinate the activities of agencies which operate at different levels of government. This paper examines these mechanisms, and their effectiveness in promoting integrated and coherent governance across multisectoral areas at national, provincial and local levels.

\section{The bottom-up approach to development planning}

The Prime Minister's Directives on Decentralisation and the Provincial Councils and Administration Act 1985 together constitute the foundation for development planning and coordination in independent Zimbabwe (Chatiza 2010). These legislative and policy initiatives provide for the establishment of a "hierarchy of representative authorities and channels of popular participation, being the village development committee (VIDCO), ward development committee (WADCO), district council and provincial council" (Herlaar and Olthof 1994, p. 10). According to Makumbe (1998), a total of 6,000 VIDCOs and 1,000 WADCOs were established when the Provincial Councils and Administration Act came into effect. These have provided an "institutional structure for horizontal coordination of development planning and implementation of central government field agencies and local authorities, viz, the district development committee and the provincial development committee" (Herlaar and Olthof 1994).

The Directives also introduced five-year and annual development planning processes for development committees, through a bottom-up procedure. In this section, the authors examine these processes to assess their effectiveness and continued relevance.

\section{Village, neighbourhood and ward level planning}

Villages and neighbourhoods are the smallest units of local government organisation in rural and urban areas respectively. Both comprise at least 120 households. The village elects a VIDCO, which is chaired by the relevant village head and is responsible for development planning, among other duties (Section 17 of the Traditional Leaders Act 1998, Chapter 29:17). In urban areas, chairpersons are elected to lead neighbourhood development committees, which are also elected by citizens of the relevant neighbourhood and charged with development planning.

Moving up the hierarchy, in general a minimum of six villages make up a ward. The WADCO consists of the chairperson and secretary of every VIDCO or neighbourhood development committee in the ward. Traditional leaders and development organisations working in the ward are also represented on the WADCO, which is chaired by a councillor (Sections 18 and 22 of the Traditional Leaders Act 1998). Its duties include the consolidation of village or neighbourhood development plans into a ward 
development plan, which is forwarded to the relevant local authority for consideration (Section 20 of the Traditional Leaders Act 1998).

\section{Local or district level planning}

Each local authority carries out development planning for its area. The planning process is spearheaded by development committees and culminates in the adoption of a local development plan (LDP).

Section 60 of the Rural District Councils Act 1988 (Chapter 29:13) requires rural district councils to establish a rural district development committee (RDDC) as one of their committees. The legislative provision provides that a RDDC should be composed of the administrative heads of rural local authorities, together with district heads of ministries and departments of the national government with district offices. Chaired by district administrators, the senior representatives of central government at the local level, RDDCs are technical committees of rural local authorities. They bolster the capacity of rural local authorities to plan, execute, monitor and evaluate development projects.

Urban local authorities are also required to adopt LDPs. Both urban and rural local authorities have an important role in land use planning and development control under the Regional, Town and Country Planning Act 1976 (Chapter 29:12) and its various amendments. They have the power to adopt spatial development plans which are supposed to be aligned with their respective strategic development plans. The national Department of Physical Planning within the ministry responsible for local government plays an important role in the adoption and implementation of such spatial plans. Under Section 46 of the Public Finance Management Act 2016 (Chapter 22:19), before the end of each financial year, local authorities are also required to submit to the national government their respective annual corporate plans, which must include the targets, outputs and outcomes they seek to achieve for the next three financial years. LDPs are partially designed to serve as tools for aligning planning and the priorities of the tiers of government at local level. When formulating these plans, local authorities should consider the development plans produced by the wards in their respective areas (Section 74(2) read together with Section 60(5) of the Rural District Councils Act 1988). They should also consider the development plans and priorities of the national government. Upon adoption by the committee and subsequently by the local authority, LDPs, together with council estimates, must be forwarded to the provincial level for consideration and inclusion in the provincial development plan (Section 74(4) of the Rural District Councils Act 1988).

\section{Provincial level planning}

As noted above, although national and local governments are functioning, provincial and metropolitan councils are yet to be established. Thus, the discussion in this section relates to the provincial structure under the old constitutional regime. 
Under this system, the provincial development plan (PDP) was formulated by provincial councils (PCs) which were responsible for development planning, implementation and evaluation (Section 14 of the Provincial Councils and Administration Act 1985). The PCs were chaired by provincial governors appointed by the president. Appointment was typically based on political affiliation to ensure effective representation of the president at the provincial level (Bland 2010). Governors were required to have close working relationships with provincial administrators and other provincial heads of ministries and agencies of the national government who, although they did not report to their respective governors, were expected to inform them of developments in the province (Makumbe 1998). When drafting the PDP, PCs were assisted by provincial development committees (PDCs), which were chaired by provincial administrators. PDC membership included town clerks, secretaries and senior officials of local authorities; senior officials of the security services; and provincial heads of each ministry and department in the province (Section 26-28 of the Provincial Councils and Administration Act 1985).

The PDP aimed to capture both long-term and short-term development priorities in the province across a variety of sectors. Ideally, it was informed by both national priorities and development plans from various local authorities in the province (Chakaipa 2010). The participation of officials at all three levels of government - national, provincial and local - in the formulation of PDPs meant that the plan was in principle a useful tool for the alignment of priorities across levels of government. Once adopted by the PC, the PDP was forwarded to the relevant national planning agency for inclusion in the National Development Plan (NDP).

\section{National level planning}

Since independence the responsibility for national development planning has shuffled between a number of institutions, including the Ministry of Finance and the Office of the President and Cabinet. These institutions have over the years produced various national development plans (NDPs) defining short- and long-term development priorities for the country, and planning agents are expected to consider PDPs in order to align the priorities of government at all levels, among other objectives. The Ministry of Local Government undertakes an important role in this process as it has a specific mandate to represent and promote the interests of sub-national governments at the national level (Pasipanodya et al. 2000; Chatiza 2010).

\section{Analysis: the failure of the bottom-up approach Village, neighbourhood and ward level}

Unfortunately, however, the bottom-up approach to development described above has failed to realise the desired outcome of integrated, coherent and responsive governance, for a number of reasons.

Development committees at village, neighbourhood and ward levels often fail to undertake development planning effectively. A range of reasons has been suggested, including a lack of necessary 
skills and the fact that such committees are not the dominant arenas for development discussions (Schou 2000). Makumbe (1996) writing in the middle of the 1990s argued that a significant number of people were unaware of the existence of these committees despite being in place for around a decade. It is in doubt if the situation improved after the year 2000. Even if they are aware, there continues to be scepticism about the role of the committees given that development planning at sub-national level continues, in practice, to be treated as a top-down process. It would also appear that synchronising the people's preferences with development plans already produced by the technical staff of councils is difficult (Chigwata 2018). Committees would require either extensive training, or reconfiguration of their membership to compensate for their lack of people with know-how on development planning.

\section{Local or district level}

At the local authority level, although RDDCs have the potential to fulfil a development planning function, in practice their composition and structure have over the years undermined their effectiveness. First, a RDDC is chaired by the district administrator, which makes it easy for national government to override development priorities expressed by residents. Second, the composition of the RDDC is weighted towards the national government's field administration, which has the effect of watering down the influence of local officials (Herlaar and Olthof 1994; Schou 2000). This is deeply problematic, as to achieve cooperative relations among governments, a relationship of equality among participants is essential; a first step towards this would be ensuring equal numbers of participants from the different tiers of government involved.

However, even if membership was reviewed there are doubts about the extent to which council and committee chairpersons would be able to influence decision-making in the RDDC (Schou 2000). This is because an entirely different set of parameters are used to arrive at decisions about projects in the RDDC. Whereas political considerations feature prominently as motivations for identifying projects at village, ward and other council committee meetings, the RDDC is guided mostly by technical considerations of the viability of projects, including cost/benefit analysis (Sibanda 2005). Although the decisions of the committee are submitted as recommendations to council, they are inevitably passed as council resolutions, due to the technical superiority of the projects (Sibanda 2005).

This raises the question of whether a committee comprised almost entirely of staff mandated to safeguard the interests and policy objectives of central government at local level should be able to override project choices informed by public consultation conducted by democratically elected councillors. Development planning at the local level in Zimbabwe has often been a highly technical activity largely undertaken by national government officials, which seldom reflects the wishes of locally elected bodies (Herlaar and Olthof 1994). Owing to a lack of capacity, local councils do not object much when central government officials finalise decisions on projects without consulting them. It has also been argued that a number of projects included in local plans are dropped by PDCs when 
formulating provincial plans as they are considered to be merely an aggregated 'shopping list' (Chigwata 2018). In addition, the effectiveness of the LDP as a tool for aligning priorities across levels of government is also questionable, given that the links between RDDCs and PDCs seem to be weak. Despite the fact that RDDCs are represented at the provincial level, PDPs have largely evolved separately from local (district) plans (Makumbe 1996). The prioritisation of projects tends to indicate a preference for central government planning rather than local planning. This is not a shortcoming of the Prime Minister's Directives themselves; but rather an indication of a need to improve the communication system and alignment strategies between provincial and local structures.

\section{Provincial level}

At provincial level, although in the past PDCs provided a platform where administrative officials of the national and local governments could consult each other on matters of mutual concern, their agendas were dominated by central government functionaries. The question arises: can officials employed by central government be relied upon to correctly interpret the wishes of people in the province? Given that the priority of these officials is to give effect to central government policy directives, the concerns of communities may be the last thing on their minds when undertaking development planning, implementation and coordination. Makumbe (1998) thus concludes that PDCs were established to spearhead the implementation of national policies at the provincial level, rather than to promote locally determined development or planning. On the other hand, PCs also failed to effectively carry out these centrally-decided policies, notably because they are not allocated budgets to realise their functions (Pasipanodya et al. 2000; Chakaipa 2010). The central government only budgets for the salary of the provincial governor (now Minister of State responsible for provincial affairs), and the limited funding allocated to the office of the provincial governor is managed by the provincial administrator - making the office of the governor, by default, an extension of the national ministry responsible for local government.

As if that were not enough, the offices of both the provincial governor and the PC are staffed by secondees from the provincial administrator's office, placing both offices within the sphere of influence of the Ministry of Local Government. Although in theory provincial governors decide the agenda of PCs, in practice those decisions are made by officers on secondment. The absence of resources has also meant that planning decisions at provincial level are not supported by budgetary allocations at the national level. Thus, structures such as PCs have been forums of mere participation without visible consequence since they cannot implement their plans. Provincial governors have always been effective in ensuring that the ruling party exercises firm control of the provinces, including local authorities.

The potential of the PDP to act as an effective tool for aligning national and local priorities has been further limited by a number of other issues. For instance, urban local authorities were reluctant to be involved in the activities of PCs which they considered lacked 'real' power (Makumbe 1996). Instead, 
the authorities considered it more useful to engage directly with the national government through the Ministry of Local Government. Hence, there was a lack of alignment between most provincial plans and those of urban local authorities, especially in cities. Furthermore, there is little evidence that PDPs were ever actually considered by the national government when determining priorities, including budget allocations (Chigwata 2018). An examination of outcomes suggests that PDPs were formulated merely to comply with the law and have not noticeably influenced practice. This buttresses the argument that in Zimbabwe the planning process is/was not synchronised with budget prioritisation at all levels of government (Chakaipa 2010).

\section{National level}

This capture of development planning and implementation by central government has failed to promote coherent, integrated and responsive government. The alignment of priorities has been significantly weakened by the lack of participation of provincial and local structures in NDPs. Although mechanisms were put in place to promote intergovernmental coordination and integration of plans at provincial and local levels, very little has been done to achieve the same ends at the national level (Chigwata 2018). Nor is there any evidence to suggest that plans from the provincial and local levels were/are considered when formulating national plans or during the annual budgeting process. Thus, popular development priorities have not been fully reflected in most NDPs since independence (see Schou 2000; MutizwaMangiza 1990).

Thus it has been difficult for the national government to mobilise support for the implementation of various NDPs over the years, and the majority of these plans were partially implemented and subsequently abandoned. The latest NDP, the Zimbabwe Agenda for Sustainable Socio-Economic Transformation ('ZimAsset'), have faced the same fate. ZimAsset covers the period 2013-2018 and seeks to "achieve sustainable development and social equity anchored on indigenisation, empowerment and employment creation which will be largely propelled by the judicious exploitation of the country's abundant human and natural resources". The plan has significant consequences for sub-national governments, especially local authorities, who under the plan have the important duty of delivering core public and social services (Government of Zimbabwe 2013b). However, evidence on the ground suggests that ZimAsset lacks essential backing from a number of key stakeholders, including some local authorities, civic groups, opposition political parties, and economic groups outside the ruling political party. Generally, civil society has been reluctant to identify with the policy objectives of ZimAsset owing to the fact that it builds on ZANU-PF election promises.

\section{Towards an effective system of intergovernmental planning and budgeting}

It is clear that the bottom-up approach to the development planning process introduced in the mid-1980s has failed to deliver the desired outcomes, producing a long list of community needs and preferences that were detached from funding priorities (Hadingham 2003). Meanwhile development planning 
continued to display a top-down approach, with ministries and agencies of national government adopting a sectoral, rather than integrated, approach to project or development planning (see Herlaar and Olthof 1994). It was thus not a surprise that the approach quickly lost credibility and was soon abandoned (Hadingham 2003).

Furthermore, the economic meltdown of the 2000s, characterised by hyperinflation, acute shortages of funding for public service delivery and a high level of 'brain-drain', made it almost impossible to undertake effective development planning at all levels of government. As a result, the centralised approach to development planning has been entrenched, which has often resulted in the formulation of plans that are detached from local needs and fraught with problems. Firstly, citizens have few opportunities to influence the development planning process, which is increasingly driven by party politics. Secondly, macro-economic planning and development planning, which ideally should be easier to mesh under a centralised approach, continue to be worlds apart (Herlaar and Olthof 1994). Thirdly, the coordination of government activities at local level continues to be weak, despite the presence of field agents of central government who are powerful relative to locally elected representatives.

\section{Recommendations}

The above analysis explains why the development process in Zimbabwe has over the years failed to realise its desired outcomes. It is against this background that the authors suggest the need to develop a new system of intergovernmental planning and budgeting that gives effect to the requirements of coherent governance in the 2013 Constitution. When developing that system, several factors must be considered to enhance its effectiveness. Three key factors are discussed below.

\section{Embed an inclusive planning and budgeting process}

Under a decentralised system of government, intergovernmental planning and budgeting is required to integrate top-down strategic obligations with the bottom-up outcomes of participatory processes (Hadingham 2003). In Zimbabwe, intergovernmental planning and budgeting has been identified as one of the mechanisms for aligning the activities of government in a multi-tiered arrangement (Department of Provincial and Local Government, South Africa 2007). The effectiveness of this tool however depends in part on how inclusive the planning and budgeting process is at all levels of government. This means that all the relevant stakeholders must be included, whether at local, provincial or national levels. Yet the discussion above reveals that the development planning and budgeting process at provincial and local levels is dominated by national government. The RDDC and PDC structures - structures established to facilitate intergovernmental planning and budgeting development planning - are dominated by the national government's technical staff (Bland 2010). They are not adequately inclusive of the sub-national governments involved. This has had the adverse effect of suffocating bottom-up planning and communication of priorities and needs to national government. The benefits of decentralisation are only likely to be realised when there is effective upward communication of local 
needs and priorities on the one hand, and consideration of such local needs and priorities by senior (higher level) governments on the other (De Visser 2005). Such effective joint working has not been realised yet in Zimbabwe.

Sub-national governments also lack representation in national decision-making processes that have a bearing on development planning and budgeting. For example, in the first and second decades of independence while sector ministries and agencies of the national government were represented in the annual Public Sector Investment Programme (PSIP) budget meetings, where the NDP and its funding priorities were set, provinces and local authorities had no representation (Schou 2000). When the economic environment deteriorated after 2000, budgeting, including the PSIP, was largely redundant partly due to inflationary pressures and the failure to mobilise revenue. There is no public evidence to suggest that in the last five years subnational governments were given opportunities to influence the national budgeting process. Even though some initiatives have involved local authorities through organised local government, these have so far not been effective in ensuring that these lower tiers of government have a significant voice in the budgeting process (Chigwata 2018). Yet the need is greater than ever. Under the old constitution, there was only one government with direct constitutional authority; but under the new constitutional order all three tiers of government have such authority. As a result, mechanisms to ensure that sub-national governments influence national decision-making processes such as planning and budgeting are now crucial.

The 2013 Constitution of Zimbabwe requires the tiers of government to coordinate their activities through intergovernmental planning and budgeting. For example, Section 194 (1)(g) of the Constitution highlights the need for the three levels of government "to cooperate with each other". However, no provision is made for achieving this. Interestingly, Section 264 (2)(e) addresses the need for equitable sharing of national and local resources between the tiers of government - but without specifying how this is to be realised. Section 165 underscores the autonomy of each level of government, suggesting that sub-national governments are fully in charge of developmental planning at their levels - yet in practice local and provincial governments, owing to lack of resources, are reduced to implementing policy programmes developed by national government. Similarly, Section 270(1)(a) of the Constitution assigns to provincial or metropolitan councils the role of planning and implementing social and economic development activities in their provinces - but these levels of government have not even been established yet, let alone granted revenue-raising powers.

Thus, even though local government has received constitutional recognition and been mandated the "right to govern", in the absence of reform the mechanisms and institutions of the 1984 and 1985 Directives and related local government legislation, which position local authorities as extensions of central government (Chatiza 2010), still guide development planning. Clearly this structure is in conflict with the 2013 Constitution, which has uplifted the status and role of local government. 
Other problems with the constitutional dispensation are also apparent, which will require cooperative intergovernmental working to resolve successfully. For example, Section 282(1)(c) of the 2013 Constitution raises a potential conflict of roles, as it assigns development functions to traditional leaders. This increases the number of actors involved in development planning, and may also undermine the role of sub-national governmental authorities as development planning authorities. The cooperation between sub-national governments and traditional leaders in the development process, is therefore pivotal to manage the conflicts and ensure that the process is as inclusive and participatory as possible (Chigwata 2015). The support, legitimacy and respect these leaders command particularly in rural areas, and their proximity to the people, are valuable strengths in development planning (Chatiza 2010; Chigwata 2015). On the financial side, the 2013 Constitution requires revenue raised nationally to be shared equitably among the three tiers of government. In particular, Section 301 provides for equitable allocation of grants between provincial councils, metropolitan councils and local tiers of government. These sub-national governments are entitled to not less than $5 \%$ of nationally raised revenue, received as grants. However, the Constitution leaves the determination of the budget allocation to national government, and sub-national bodies have no way of ensuring the adequacy of such allocations or of actually securing the funds, even though they affect their financial sustainability. Effective intergovernmental development planning and budgeting becomes important to address this constitutional deficiency.

\section{Strive to establish a close link between intergovernmental planning and budgeting}

A second reason why the development planning process in Zimbabwe has failed to realise the desired outcomes is that it is "secondary to the financial aspects of decentralisation and other development objectives" (Hadingham 2003). There is often a gap between what is agreed in development plans and what is prioritised in budgets. Even though planning at provincial and local levels involves officials from national government and local authorities, budgeting and policy implementation occurs separately. Officials of national government work on sectoral lines whilst local officials implement policies determined by their respective councils. As a result, the production of short- and long-term plans was considered in the 1990 s to be a 'barren ritual' as very few of the proposed projects in any year are budgeted for, funded or subsequently implemented (Mutizwa-Mangiza 1990). This picture still prevailing under the 2013 Constitution. If the intergovernmental planning and budgeting process is to be effective in coordinating government activities in Zimbabwe, a close link between planning and budgeting is essential at all levels of government (Chigwata 2018). This is the only way of guaranteeing the implementation of development plans. As provincial and local governments are entitled to not less than $5 \%$ of national revenue in each financial year, constitutional provisions should be implemented and this revenue should be closely linked with spending priorities, as defined in the intergovernmental planning process. 


\section{Identify a 'champion' for intergovernmental planning and budgeting}

As argued above, a functioning intergovernmental planning and budgeting process is critical in a country with a multi-level system of government. It cannot be left to the 'goodwill' of political office bearers and public servants. In Zimbabwe, there is a need to establish an institution charged with championing intergovernmental planning and budgeting. Such an institution must command respect across all organs of government at all levels. The current arrangement where the Office of the President and Cabinet is charged with overseeing the implementation of the NDP, the ZimAsset, is commendable. Perhaps the same Office should be assigned overall responsibility to drive intergovernmental planning and budgeting, in addition to overseeing the implementation of development plans at provincial and local levels. It should have a mandate to ensure that the goals of coherent, harmonised, coordinated and cooperative government set out in Section 265 of the Constitution of Zimbabwe are realised.

The constitutional framework is clear. Section 194(1)(g) of the 2013 Constitution requires the three tiers of government to cooperate with one another. The Constitution directs the national government to take measures to promote cooperative governance and coordination of government activities (Section 265(3)). It specifically assigns provincial and metropolitan councils (PMCs) the duty to coordinate and implement government policies. These councils are to be composed of members of both the national and local governments (Sections 268(1) and 269(1) of the Constitution), making them suitable institutions to foster coordination between the national and local governments on areas of mutual interest, including implementation of national legislation and policies. The Constitution also assigns to these PMCs the responsibility for coordinating government activities and monitoring use of public resources (Section 270), tasks which have a direct bearing on intergovernmental relations. It would appear therefore that the Constitution envisions them as facilitating cooperation and coordination between the tiers of government.

This paper therefore recommends that national legislation be established which assigns additional responsibilities on intergovernmental planning and budgeting to PMCs. PMCs could also: discuss and consult on provincial implementation of national policies and legislation; draft national policies and legislation affecting provinces and local authorities; develop provincial policies, and consider reports from local-level structures such as RDDCs.

\section{Conclusion}

Intergovernmental planning and budgeting is one tool for aligning government activities under a decentralised system of government such as Zimbabwe's. Since independence, the national government in Zimbabwe has established structures and procedures for aligning priorities and coordinating government activities based on a 'bottom-up' approach. However, this has failed to deliver integrated, coherent and responsive government for a number of reasons, including the domination of relevant structures at sub-national level by the officials of the national government. The lack of sub-national 
representation in national decision-making structures that undertake planning and budgeting has also been identified as an impediment to effective alignment of government priorities at the national level.

The adoption of Zimbabwe's new Constitution has provided an opportunity to reform the development planning and development process. This paper suggests the establishment of a new system of intergovernmental planning and budgeting that is inclusive, participatory and that strives to establish a close link between development planning and budgeting. In addition, a respected institution, such as the Office of the President and Cabinet, should be charged with the overall objective of ensuring integrated, coherent and responsive government.

\section{Declaration of conflicting interest}

The authors declared no potential conflicts of interest with respect to the research, authorship, and/or publication of this article.

\section{Funding}

The authors received no financial support for the research, authorship, and/or publication of this article.

\section{References}

Bland, G. (2010) Zimbabwe in transition: What about the local level. North Carolina: RTI Press. https://doi.org/10.3768/rtipress.2010.op.0003.1009

Chakaipa, S. (2010) Local government institutions and elections. In: De Visser, J., Steytler, N. and Machingauta, N. (2010) Local government in Zimbabwe: A policy dialogue. (pp. 31-68). Bellville: Community Law Centre, University of the Western Cape.

Chatiza, K. (2010) Can local government steer socio-economic transformation in Zimbabwe? Analysing historical trends and gazing the future. In: De Visser, J., Steytler, N. and Machingauta, N. (2010) Local government in Zimbabwe: A policy dialogue. (pp. 1-25). Bellville: Community Law Centre, University of the Western Cape.

Chigwata, T.C. (2015) Decentralisation in Africa and the resilience of traditional authorities: Evaluating Zimbabwe's track record. Regional and Federal Studies, 25 (5), 439-453. https://doi.org/10.1080/13597566.2015.1121873

Chigwata, T.C. (2018) The law and policy on provincial and local government in Zimbabwe. Juta: Cape Town (in press).

De Visser, J. (2005) Developmental local government: A case study of South Africa. Antwerpen: Intersentia.

Department of Provincial and Local Government, South Africa. (2007) Practitioner's guide to intergovernmental relations in South Africa. Pretoria: Department of Provincial and Local Government.

Government of Zimbabwe. (1976) Regional, Town and Country Planning Act, Act 22 of 1976, Chapter 29:12. Harare: Government Printers.

Government of Zimbabwe. (1984) Provincial councils and administration in Zimbabwe: A statement of policy and a directive by the Prime Minister's directives on decentralisation and development. Harare: Ministry of Local Government, Rural and Urban Development.

Government of Zimbabwe (1985) Provincial Councils and Administration Act, Chapter 29:11. Harare: Government Printers.

Government of Zimbabwe. (1988) Rural District Councils Act, Act 8 of 1988, Chapter 29:13. Harare: Government Printers. 
Government of Zimbabwe (1998) Traditional Leaders Act, Act 25 of 1998, Chapter 29:17. Harare: Government Printers.

Government of Zimbabwe. (2013a) Constitution of Zimbabwe Amendment (Number 20) Act 2013. Harare: Government Printers.

Government of Zimbabwe. (2013b) Zimbabwe agenda for sustainable socio-economic transformation (ZimAsset) 'Towards an empowered society and a growing economy'. Harare: Government of Zimbabwe.

Government of Zimbabwe. (2016) Public Finance Management Act, Act 6 of 2016, Chapter 22:19. Harare: Government Printers.

Hadingham, T. (2003) Decentralisation and development planning: Some practical considerations. International Labour Organisation. Available at http://www.ilo.org/wcmsp5/groups/public/@ed_emp/@emp_policy/@invest/documents/publication/wc ms_asist_8213.pdf [Accessed 05 March 2018].

Herlaar, M. and Olthof, W. (1994) Rural local government and development planning, with experiences from Buhera District, Zimbabwe. Working Papers. The Hague, The Netherlands: Institute of Social Studies.

Makumbe, J. (1996) Participatory development: The case of Zimbabwe. Harare: University of Zimbabwe Publications.

Makumbe, J. (1998) Democracy and development in Zimbabwe: Constraints on decentralisation. Harare, Zimbabwe: SAPES.

Mutizwa-Mangiza, N.D. (1990) Decentralisation and district development planning in Zimbabwe. Public Administration and Development, 10, 423-435. https://doi.org/10.1002/pad.4230100406

Pasipanodya, D., Steffensen, J., Trollegaard, S., Martin, R., Khumalo, C., Chando, V. and Ncube, D. (2000) Fiscal decentralisation and subnational government finance in relation to infrastructure and service provision in Zimbabwe. World Bank series of reports on fiscal decentralisation and sub-national finance in Africa, Proceedings of the Conference held at Kadoma Hotel and Conference Centre, Zimbabwe on 89 February 2000.

Schou, A. (2000) Democratic local government and responsiveness: Lessons from Zimbabwe and Tanzania. Sociology, 41 (1), 121-143.

Sibanda, H. (2005) Participatory planning in rural local government: opportunities and challenges, 1-5. A paper presented at a workshop on rural local government held at Rushinga Rural Service Centre, Zimbabwe, 15-16 September 2005. 